\title{
Towards Restoring Infiltration in Permeable Pavers-Initial Demonstration of Rapid Clean-Out Concepts
}

\author{
William James ${ }^{1}$ and Harald von Langsdorff ${ }^{2}$ \\ ${ }^{1}$ CHI, Guelph, Ontario; ${ }^{2}$ F. Von Langsdorff Licensing Limited, Caledon, Ontario.
}

\begin{abstract}
Where clogging of drainage cells in permeable interlocking concrete pavers (PICPs) is dominantly in the upper parts of the filter media, as it is in most cases, infiltration rates in special PICPs may be rapidly restored if the PICP design is dovetailed to the fluid mechanics of the street cleaning equipment. PICPs described in this paper have special purpose cupules (shaped filter recesses in the upper surface of the block) for rapid cleaning, which are connected to drainage conduits. These cupules facilitate rapid removal of filter media and filtrate by routine street cleaning equipment at economical speeds. Below the cupules, the drainage conduits are designed to provide specified maximum or controlled drainage flow rates. Further, geometry of the resulting drainage cell also meets the requirements of the Americans with Disability Act as well as certain requirements for mass production.

To develop these special PICPs_-here denoted RCPPs (rapidly cleaned permeable pavers)—experiments were carried out in Guelph, Southern Ontario. This paper describes initial RCPP demonstrations using a rig designed to reveal the fluid mechanics and performance of a regenerative air cleaner moving horizontally over test blocks having the same geometry as the RCPPs, and filled with non-cohesive filter aggregate. Note that these tests were designed to examine the dynamic fluid mechanics of the removal of filter media by a moving pick-up head, as affected by geometrical variables only. In our continuing experiments, the independent variables are: $V$, speed of cleaning equipment over the pavement; $\theta$, angle of the cleaning jets; $v$, air velocity in the cleaning jets; $d$ and $\varphi$, geometry of the cupules; $w$, width of drainage conduit; and $G$, gradation of the filter media. $S$, the ratio of the mass of removed and captured to the original mass of cupule filter media (plus filtrate), is the dependent variable. $S$ is measured by weighing the aggregate added when replacing that removed by the regenerative air vortices, and dividing by the original weight of the aggregate in the cupule. Our laboratory experiments demonstrated that, for the chosen geometries and filter aggregate, complete removal $(S \geq 1.0)$ is easily achieved in one pass at reasonable speed. The paper describes our experimental rig and demonstrates the cleanout concepts, and includes CAD files of detailed drawings of the components of the rig and test blocks, as well as slow motion video clips of the clean out processes.
\end{abstract}

In essence, the new RCPP promises ready capture of particulates and pollutants attached to them by routine (routine meaning conventional, or off-the-shelf, non-special-purpose) regenerative-air street cleaning equipment. Evidently these RCPPs could significantly advance environmental protection, by rendering clean-out more effective and more economical.

\section{Introduction}

Over the past several decades, with increasing concerns about restoring the natural environment, stormwater management practices have progressed towards simultaneous quantity and quality control, and away from facilities such as single, endof-pipe detention ponds. Further, modern techniques seek to simultaneously accept intense rainfall rates, while lowering stormwater runoff volumes, recharging groundwater, mitigating contaminant transport and restoring natural aquatic ecosystem attributes. One such low impact stormwater management practice (LID) is permeable interlocking concrete paving (PICP). Whereas impervious areas are associated with increased flows, contaminant concentrations and loads, PICP, by allowing water to infiltrate into the subsurface layers, has an effect that tends towards imitation of pre-development hydrologic regimes. PICP not only reduces surface runoff but may recharge groundwater (or capture stormwater for reuse) and reduce pollutants reaching receiving waters (Schueler 1987). The author studied PICP in the period 1994 to 2004, as reviewed below. An early study of long term PICP performance, over decades, by Pratt et al. (1995), was

James, William and Harald von Langsdorff. Towards Restoring Infiltration in Permeable Pavers-Initial Demonstration of Rapid Clean-Out Concepts. Journal of Water Management Modeling 25:C405. https://doi.org/10.14796/JWMM.C405 @ CHI 2016. www.chijournal.org ISSN $2292-6062$. 
followed in the period 2003 to 2008 by studies by Brattebo and Booth (2003), Sansalone and Teng (2004), Bean et al. (2007b) and Sansalone et al. (2008).

Whether planning, designing, constructing or managing a PICP installation, it is fundamentally important to provide and maintain surface infiltration capacity, allowing an adequate volume of stormwater to be captured and treated by the facility. PICP infiltration capacity is dependent upon factors such as drainage cell density and permeability; surface slope; surface ponding; pavement base permeability, drainage and void volume; grading and quantity of surface dust and dirt applied; duration and intensity of applied surface loads (such as traffic); and, above all, upon proper pavement management. Designing and constructing a new system to provide appropriately high infiltration capacities is not problematic, but maintaining infiltration capacities over several years has proven to be a concern, if not actually challenging. This is the nub of the present paper.

Below we first review some earlier published work, including our own, that is readily available in the public domain, mostly through the Journal of Water Management Modeling (JWMM; https://www.chijournal.org/; search for relevant papers by entering a simplified search term, PAV for instance).

\section{Background-Early Studies at the Uni- versity of Guelph}

Excellent work has been done by others on this and related topics, which we do review, however we tend to review much of our own work, since it was generally done earlier.

Thompson (1995) and Thompson and James (1995) describe the design, construction and instrumentation of four different pavements - asphalt (AS), concrete brick (CP), and 3 in. $(76 \mathrm{~mm})$ and 4 in. (102 $\mathrm{mm}$ ) thick concrete paver stones with infiltration cells (E3 and E4)_installed in both a typical parking lot and a laboratory rig, for studies of the flux of 23 contaminants including heat. In a follow-up paper James and Thompson (1997) report conclusions obtained from the parking lot pavements after the first year. (Some of their results are given in Figure 1 below). Their test pavements and laboratory rigs were used in much of the ensuing research reported below.

In their laboratory tests, Shahin (1994), Thompson and James (1995), and James and Verspagen (1997) confirmed low runoff volumes from the upper surface of permeable concrete pavers that were not subjected to wear or pollutant deposition on the PICP surfaces, and therefore performed under optimum conditions. Kresin et al. (1997), on the other hand, using the rainfall simulating infiltrometer rig shown in Figure 2, collected data at several existing outdoor Uni-Ecostone permeable concrete paver installations, and tested the hypotheses that infiltration capacities decrease with age and certain land uses; and that infiltration capacities are improved by street sweeping or vacuuming the surface. They showed a significant relationship between overall effective infiltration capacity (fEo) and pavement age: as
Uni-Ecostone installations aged, fEo decreased. Also significant is the relationship between fEo and the degree of compaction (defined as travelled or untravelled). An improvement in fEo can be obtained by removal of the relatively thin top layer of external drainage cell (EDC) material, which they denoted the EDC crust.

Heavy Metal Concentrations for Eco-Stone 3" and Eco-Stone 4" Compared to Ontario Ministry of the Environment Guidelines

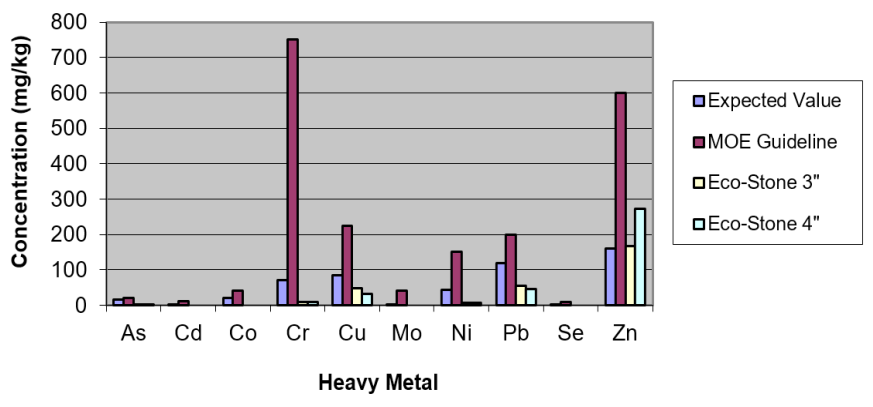

Figure 1 Comparison with the Ontario MOE guideline concentrations for selected metals in soils (blue = expected value; purple $=$ MOE guidelines; yellow $=$ EcoStone 3 in.; green = EcoStone 4 in.).

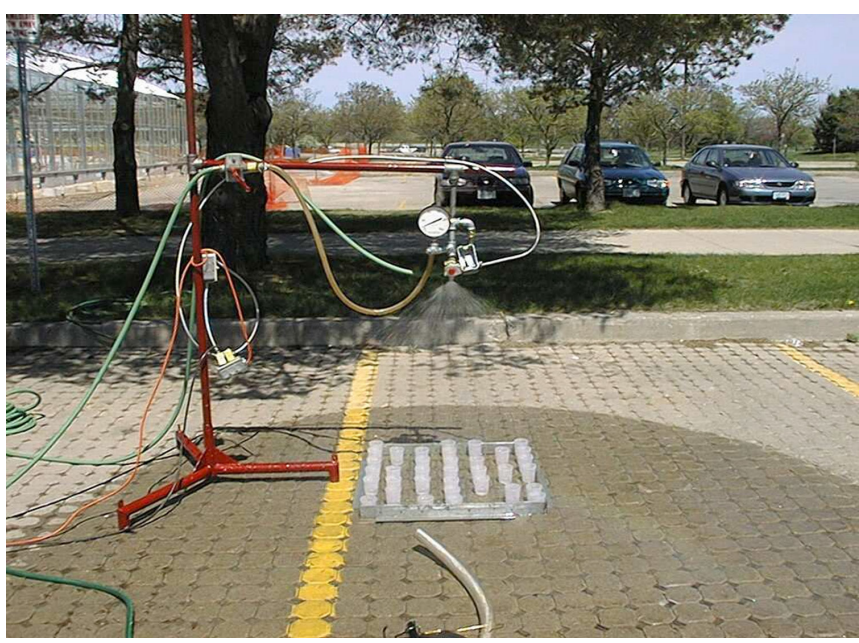

Figure 2 Rainfall simulator for surface infiltration tests on the parking lot test pavements.

Much later, the then $8 \mathrm{y}$ old installation of two different types of permeable pavements in the parking lot were studied between 2001-05 and 2001-09 by James and Gerrits (2003), concentrating on the decrease in infiltration capacity with age and increased traffic use, as well as methods of restoring the infiltration capacity of PICP, for example by street sweeping or vacuuming the surface. They confirmed the by-then obvious fact that, as permeable paver installations age, or are heavily used, infiltration capacity decreases due to the clogging of the external drainage cell (EDC) with fines (silt and clay), organic matter, and extractable solvents from automobiles (primarily oil and grease). In the pavers the drainage cells were vertical-sided, with chamfers, and there were no cupules. No special pavement maintenance procedures 
were used over the $8 \mathrm{y}$ period, other than routine snow removal and street sweeping with rotating brushes annually in spring and fall. In their tests, infiltration rates were tested before and after material was extracted from the EDCs and replaced by fresh aggregate. Extracted material was subjected to a particle size and constituent analysis and tested for a number of different organic and chemical constituents such as heavy metals, nutrients and organic matter. By manually removing the drainage cell material, as shown in Figures 3 and 4, and by repeating the infiltrometer measurements at each layer, they again confirmed that infiltration capacity decreased with increasing average daily traffic counts, and as the amount of organic matter and fine matter in the EDC material increased. Furthermore, the tests indicated that the infiltration capacity can be significantly improved by removing only the top $10 \mathrm{~mm}$ to $25 \mathrm{~mm}$ EDC material, a removal depth that was deemed achievable. Results are shown in Figure 5. Later research confirms the findings in this figure (Gerrits and James 2002).

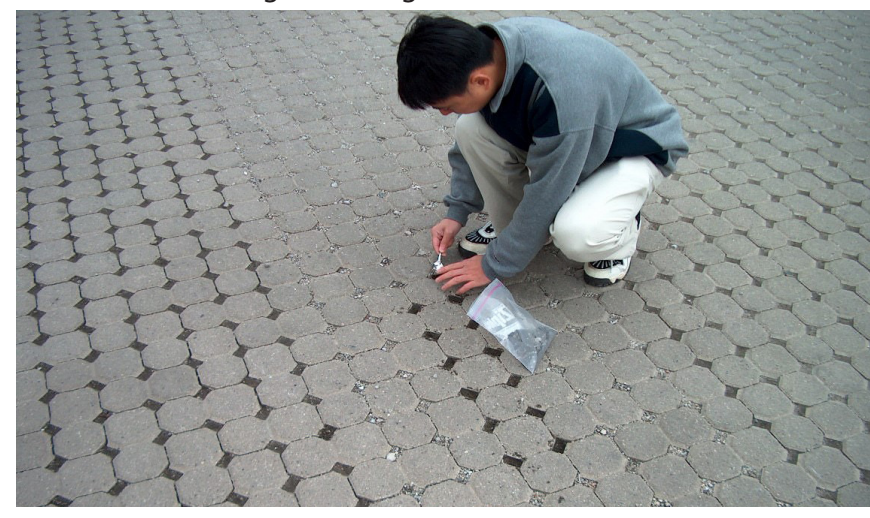

Figure 3 Manual removal and capture of filter and filtrate material in the drainage cells of permeable pavers.

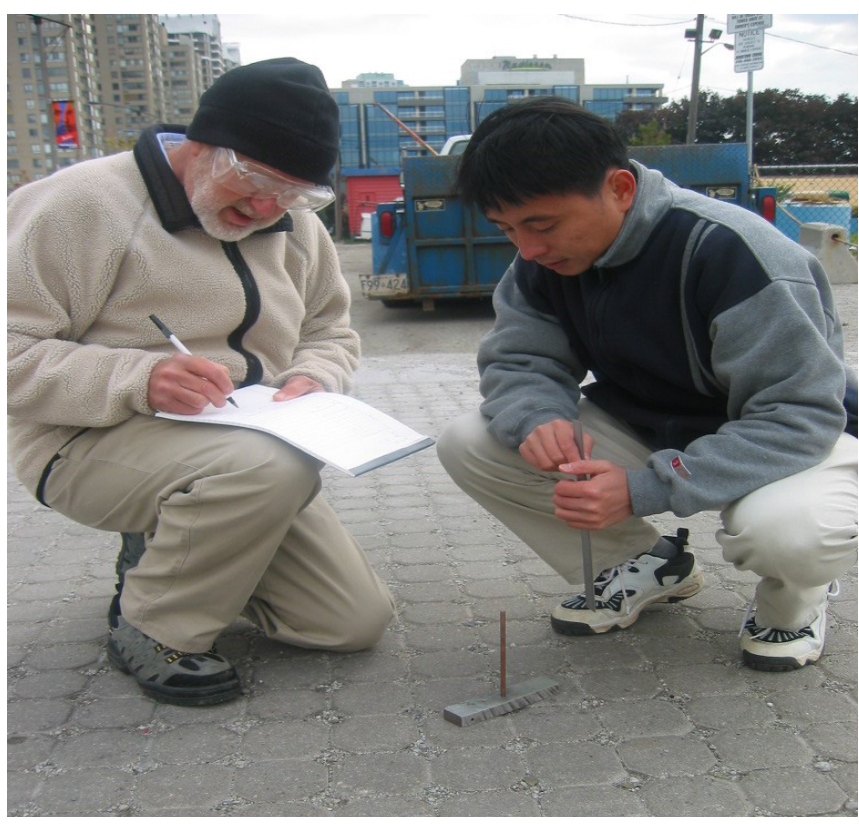

Figure 4 Measurement of removed depths of filter and filtrate material in drainage cells.

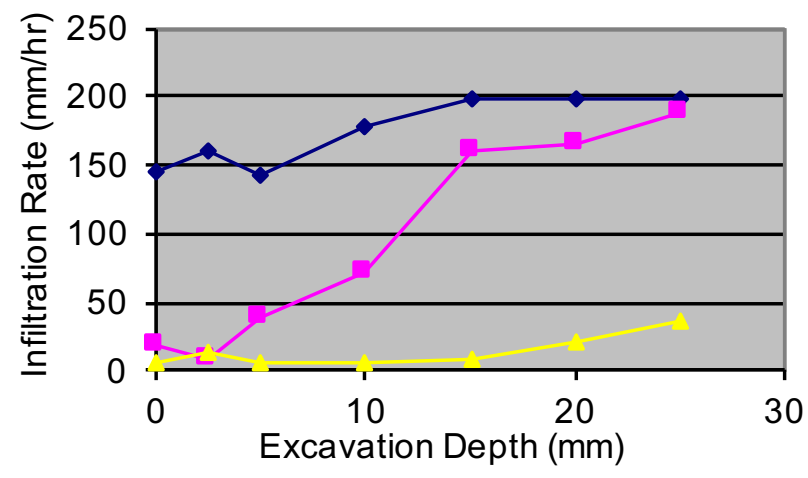

Figure 5 Infiltration capacity vs depth for MICBEC3 installation; the maximum rain rate that could be applied was $200 \mathrm{~mm} / \mathrm{h}$ (blue = low ADT; purple = medium ADT; yellow = high ADT).

James (2004) studied clogging of PICPs in a full-scale outdoor test rig having a pavement surface area of $1 \mathrm{~m}^{2}$. Samples of parking lot dust and dirt (D\&D) were collected from existing PICP installations and processed to remove moisture and volatile compounds, as well as biological vectors. Samples were analyzed for their particle size distribution. City street D\&D was collected in large quantities, similarly processed and reconstituted into the same fractions found on the permeable paver surface. Tests were then conducted on the special outdoor rig. Synthesized D\&D and artificial, intense rains were systematically applied to the pavement, and surface and subsurface drainage flow rates measured. Four different PICPs were tested and drainage cell, bedding and base material throughout the test pavement were sampled and analyzed. Typical results are shown in Figure 6 and indicate the rate at which the synthesized D\&D (SD\&D, denoted sediment in Figure 6) may clog the drainage cells of PICP.

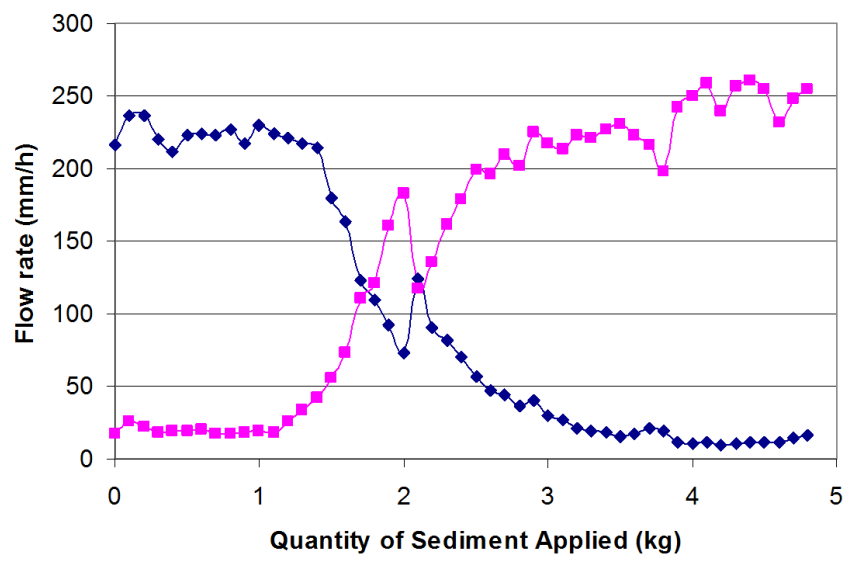

Figure 6 Summary of the change in the peak base drainage and surface runoff due to SD\&D application (squares = peak base drainage, diamonds = average peak surface runoff; the anomalous blip at $2 \mathrm{~kg}$ is the result of a weekend delay in the experiment). 
Change in the performance (infiltration rates) of the permeable pavers as a result of the SD\&D application did not begin immediately. Quantities of SD\&D that can be applied without causing a decline in performance of the pavers are evidently determined by the net porosity of the combined drainage cell fill material and applied SD\&D. After the application of $1.4 \mathrm{~kg} /$ $\mathrm{m}^{2}$ of road SD\&D, the average infiltration rate at the paver surface declined to a rate below the inflow rates (using a 1 in $25 \mathrm{y}$ design storm of 5 min duration and intensity of $230 \mathrm{~mm} / \mathrm{h}$ ). More frequently observed rainfall events with lower rainfall intensities might produce different results. After the accumulation of $3.9 \mathrm{~kg} / \mathrm{m}^{2} \mathrm{SD} \& \mathrm{D}$, the drainage cell material became functionally clogged. However, over a large section of permeable pavers, heterogeneity of the infiltration rates over different sections may sustain the performance of the pavers for some time. PICP should be properly maintained when there is a risk that the surface is affected by partial clogging. This should correspond to the accumulation of between $1.4 \mathrm{~kg} / \mathrm{m}^{2}$ and $3.9 \mathrm{~kg} / \mathrm{m}^{2}$ SD\&D for the conditions of their experiment. James recommended that his results be compared to similar experiments using different drainage cell and base materials of varying porosity, and using different rainfall intensities and durations. Also, in future experiments, SD\&D remaining on the surface should be carefully measured, to formulate a SD\&D balance, and help determine SD\&D pathways and fate.

\section{Later Studies}

In the period 2005 to 2015, surface infiltration and its change over time, clogging, were studied by Bean et al. (2007a), Lucke and Beecham (2011) and Nichols et al. (2015).

Bean et al. (2005) tested the surface infiltration rate of 27 permeable pavement sites in North Carolina, Maryland and Delaware. Concrete grid pavers (CGP) and permeable interlocking concrete pavers were tested with pavement ages ranging from $0.5 \mathrm{y}$ to $20 \mathrm{y}$. They conducted two infiltration tests on 14 CGP lots filled with sand: first on the existing condition of the surface and secondly after the removal of the top layer of residue $(13 \mathrm{~mm}$ to $19 \mathrm{~mm}$ ). This pseudo-maintenance improved the median average infiltration rate on 13 of 14 sites, at a confidence level of $99.8 \%$, from $50 \mathrm{~mm} / \mathrm{h}$ to $80 \mathrm{~mm} / \mathrm{h}$. Eleven PICP sites were also tested, and it was found that sites built near a source of loose fine particles had infiltration rates significantly less than sites free of loose fines, with observed averages of $600 \mathrm{~mm} / \mathrm{h}$ and $20000 \mathrm{~mm} / \mathrm{h}$ respectively.

In a Canadian study, Drake and Bradford (2013a) once again reiterate that the removal of surface material restores infiltration, and they presented the results and experiences of using regenerative air and vacuum sweeping trucks on permeable pavements in Ontario. A regenerative air truck was tested on two parking lots with well used PICP and pervious concrete while a vacuum sweeping truck was tested on a third parking lot with PICP. Both systems provided partial rehabilitation of the permeable pavements. They confirmed the findings of James and Gerrits (2003) that (1) post-treatment surface infiltration rates on all three parking lots displayed large spatial variability suggesting that "micro-conditions confound overall effectiveness of maintenance"; and (2) performance may be improved by regular cleaning along instructional guidelines stressing preventive maintenance over rehabilitation.

The Toronto Regional Conservation Authority (TRCA 2015) monitored a parking lot that was constructed with conventional asphalt, pervious concrete and two types of PICP: UNI-Optiloc with a joint width of $\sim 25 \mathrm{~mm}$, and AquaPave having a joint width of $13 \mathrm{~mm}$. Study findings from their Phase II Full Report also confirm that PICP is effective for infiltration, even in areas with low permeability soils, but declines rapidly over the first two years, and may be partially restored by vacuum cleaning.

These findings led us to develop design and modelling tools for PICP as a LID. Kipkie and James (2000) examined the feasibility of code for the U.S. Environmental Protection Agency Storm Water Management Model (SWMM) to allow planners and designers to simulate the responses of permeable pavements in long term modeling applications. Infiltration capacity of the permeable pavers was based on available studies, taking into account degradation over time and regeneration by mechanical means. James et al. (2001) later detailed the underlying method and function of a freeware program that also used SWMM (and PCSWMM) for the design of permeable pavements and was also based on the sum of W. James's research reviewed above. Later, SWMM5 incorporated similar routines, and these continue to enjoy wide use.

Finally, it could be mentioned that proposals for smart systems aimed at efficiently restoring the special PICPs, in the spirit of those described by James (2000), and described in the next part of this paper, are currently under consideration at $\mathrm{CHI}$ by the principal author.

\section{Methodology}

Researchers evidently differ on methods for restoring PICP infiltration: Henderson and Tighe (2011) recommend fire or power hosing, whereas Chopra et al. (2010) and Drake and Bradford (2013a; 2013b) examined vacuum sweeping. Winston et al. (2016) found that vacuuming does not restore infiltration capacity. Thus we decided to design a PICP stone that would mesh with the surface processes of effective, conventional street sweepers. In this paper regenerative air street sweepers are emulated.

Our original infiltration tests were conducted on UNI-Ecostone with relatively large rectangular voids, $38 \mathrm{~mm} \times 50 \mathrm{~mm}$. The 2010 Americans with Disability Act (ADA) Standards for Accessible Design stipulates that openings in floor or ground surfaces shall not allow passage of a sphere of more than $0.5 \mathrm{in}$. $(13 \mathrm{~mm})$ diameter. Obviously this obligation limits the maximum width of infiltration cupules and increases the difficulty of maintaining adequate long term infiltration rates on conforming PICPs, especially if a strict maintenance scheduled is not followed. Furthermore, where PICPs are mass produced, the manufacturing process itself imposes certain constraints. 
For these reasons we decided to proceed with laboratory scale demonstrations of the basic fluid mechanics in various geometries of RCPPs, as they are swept and cleaned by a simulated pick-up head with similar air flow patterns and speeds to those of real, full scale machines-earlier work reviewed above suggested the suitability of regenerative air street sweepers, now the second most popular equipment, for which engineering details are provided in Figures 7 and 8, courtesy of Johnston Street Sweepers, and AMACO Canada. Air flow rates for such equipment is approximately $20000 \mathrm{ft}^{3} / \mathrm{min}(566000 \mathrm{~L} / \mathrm{min})$. In the rig developed for this paper, at an airflow of $200 \mathrm{ft}^{3} / \mathrm{min}$ (5 $660 \mathrm{~L} / \mathrm{min}$ ) air velocities in the simulated pick-up head are matched by scaling down the length of the air supply slot (sometimes termed the blast jet.

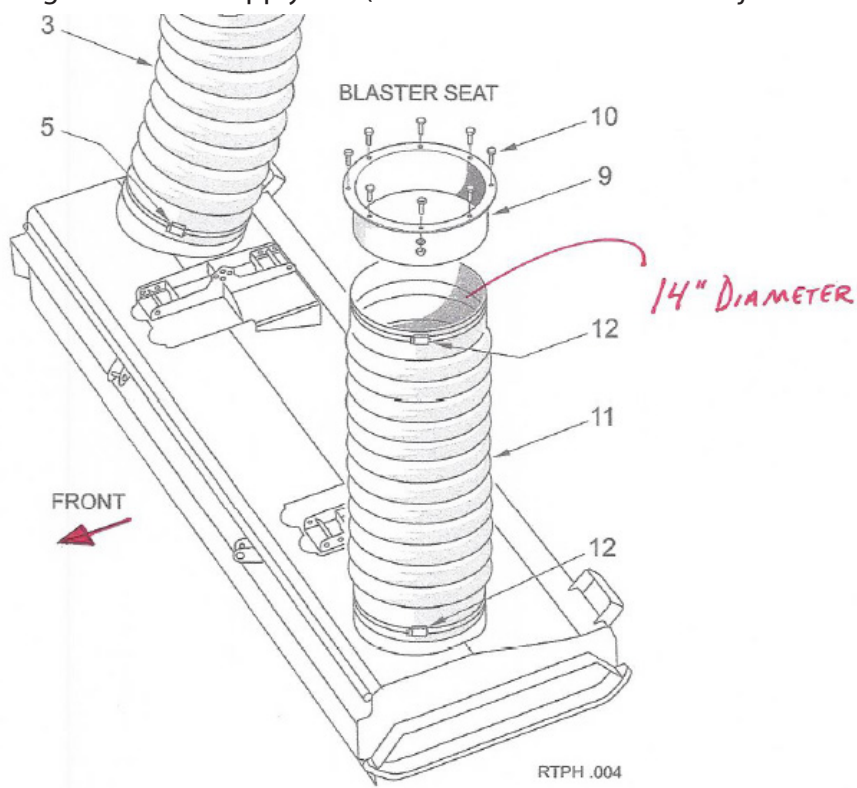

Figure 7 Pick-up head, detail (source: Johnston Street Sweepers, AMACO Canada).

\section{PICK-UP NOZZLE LEFT SIDE CUT-AWAY}

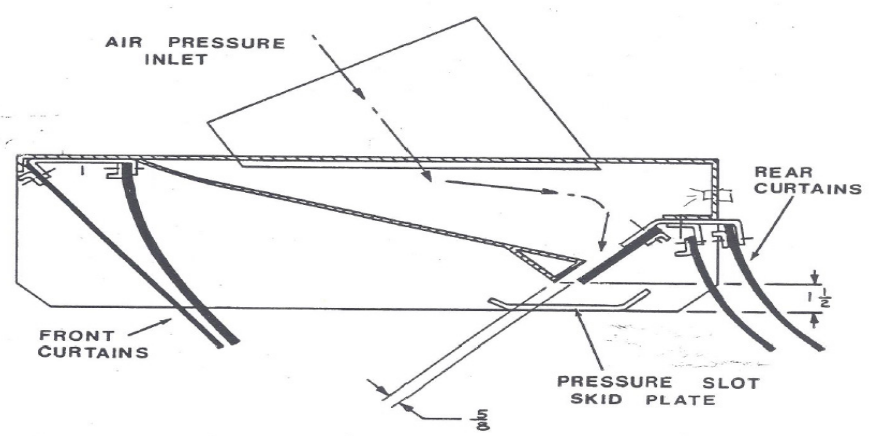

Figure 8 Cross section, regenerative air pick-up head (source: Johnston Street Sweepers, AMACO Canada).

\section{Test Rig, Test RCPPs and Discussion}

Fully dimensioned AutoCad drawings of the components of the rig, see Figure 14 below, and of the RCPP test specimen, are attached as files to this online paper. Briefly, a number of test RCPPs were machined in clear poplar, as shown in Figures 9 and 10. A single RCPP was inserted in the rectangular plexiglass ampule (housing) shown in Figure 11. Bedding, conduit and cupule filter media were poured into the ampule, the RCPP tamped down and the assembly paced in the test rig, as depicted in Figure 12. Connected to the regenerative air source, the test pick-up head passed over the RCPP at speed, as can be discerned from Figure 13. Figure 14 shows a test version of one regenerative air pick-up head, which simulated the fluid mechanics of a pick-up head by manufacturer $\mathrm{J}$.

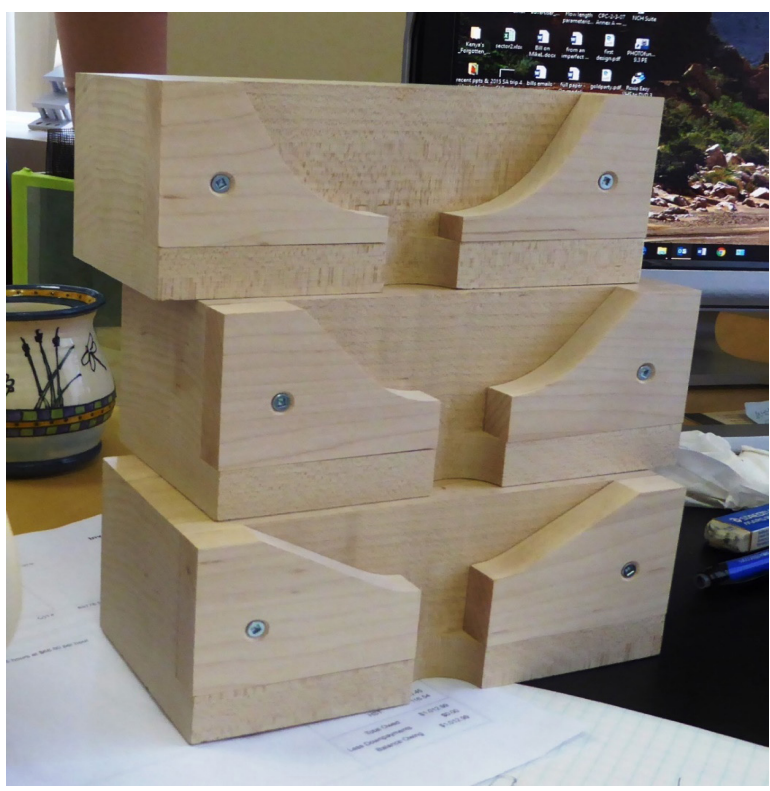

Figure 9 Several test PICPs.

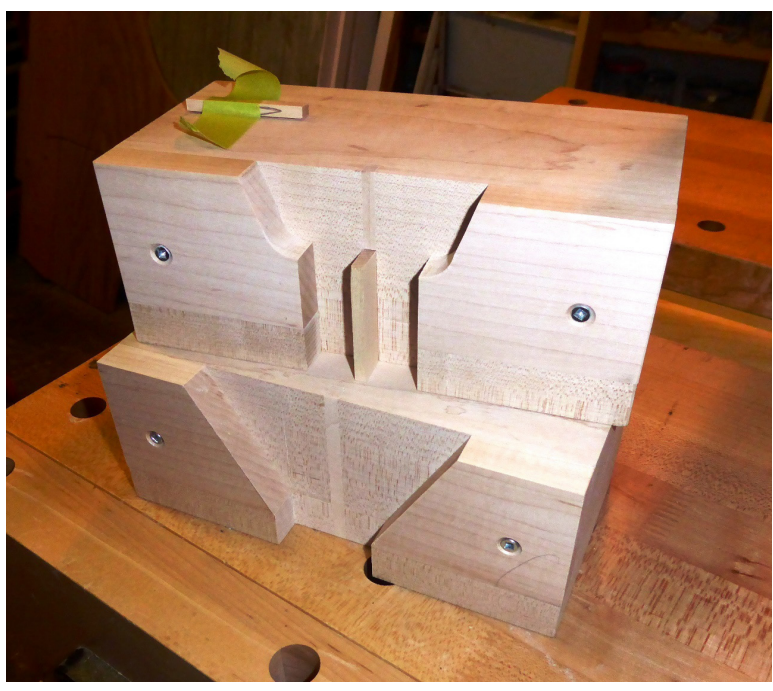

Figure 10 Further test PICPs. 


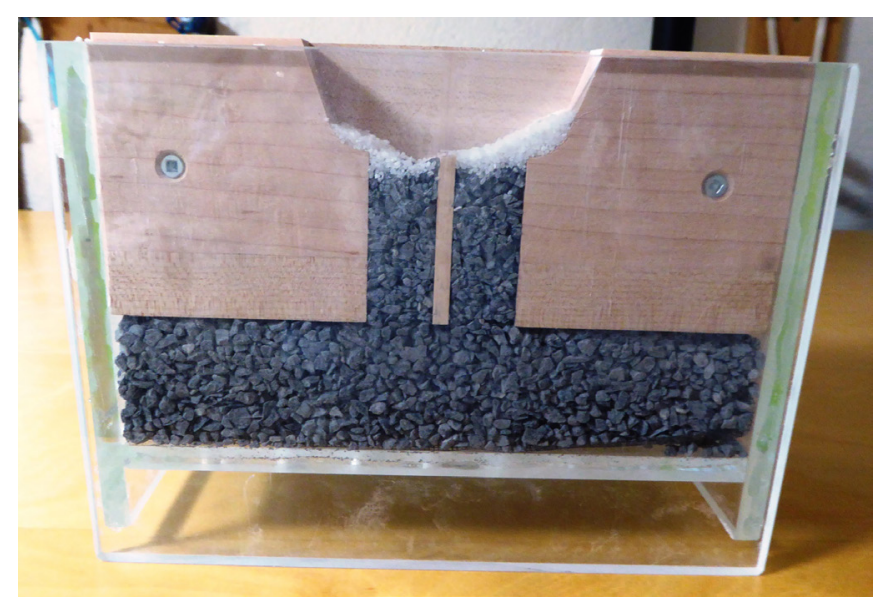

Figure 11 Test block with filter media in the ampule.

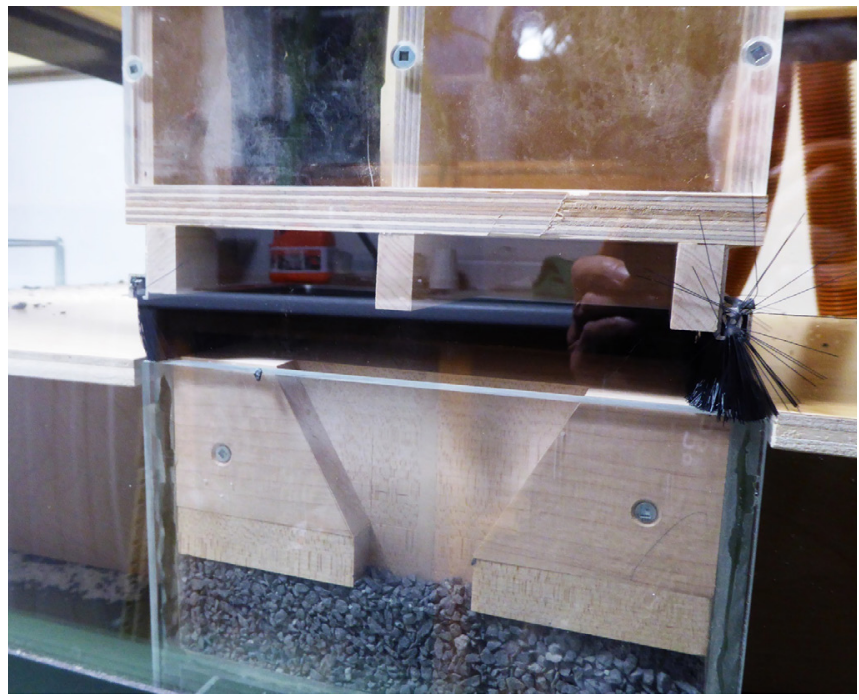

Figure 12 Loaded ampule positioned in test section of the rig.

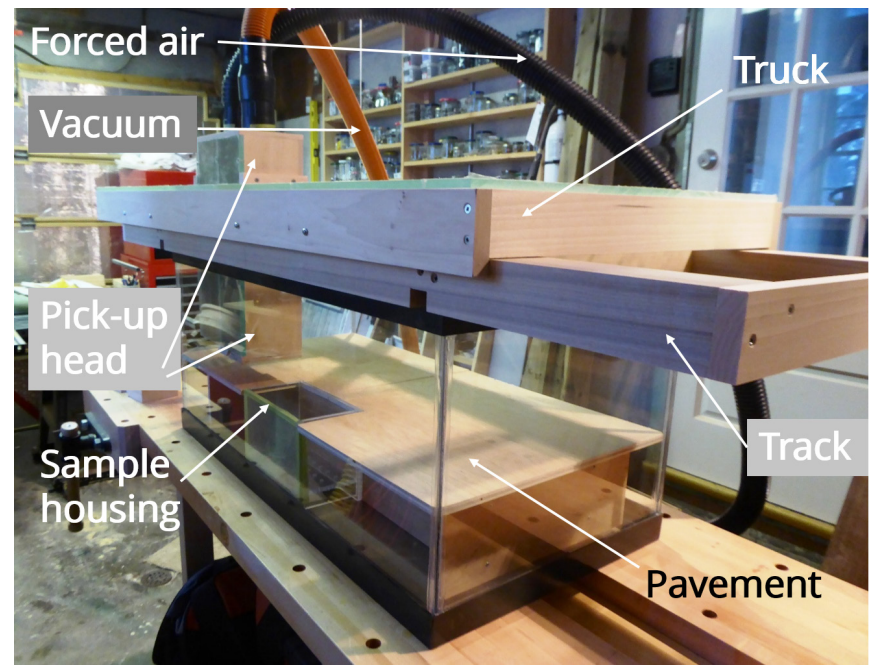

Figure 13 Rig, general arrangement.

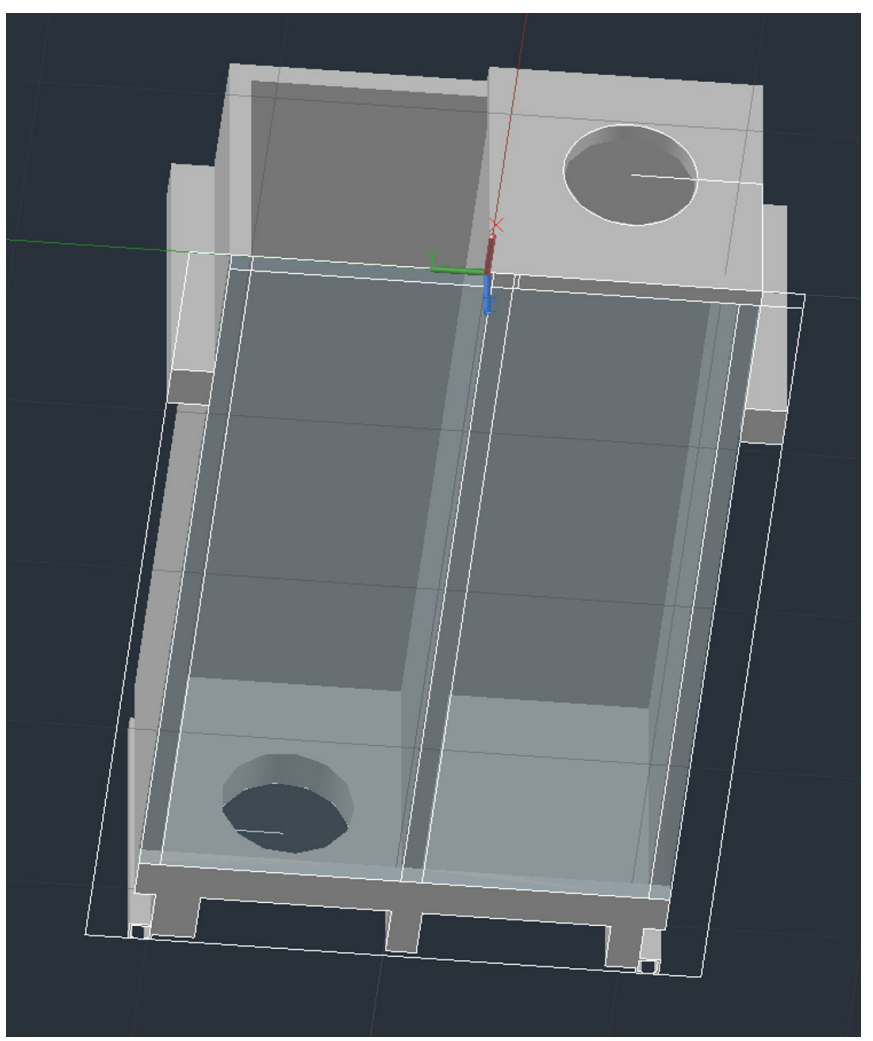

Figure 14 Schematic outline for test pick-up head J (some details missing).

A slow motion video with timing (available from $\mathrm{CHI}$ ) clearly illustrates the flow patterns of the ejected filter media as the pick-up head passes over the test section, with vacuum leading and blast air jets following. The first pass ejects a slightly greater volume of media than in the cupule, and the return pass does not significantly remove further media. From the timing we calculate the horizontal truck speed as $800 \mathrm{~m} / \mathrm{h}$ or slightly under $1 \mathrm{~km} / \mathrm{h}$.

Further tests in the laboratory rig showed that, for the chosen geometries, virtually complete removal, $S \approx 1.0$, or even excessive removal, $S \geq 1.0$, is easily achieved at almost any reasonable speed $V$. Figure 12 above shows one such result.

Tests on these new RCCPs are being carried out to determine the functional relationship for $S$, the ratio of mass of removed and captured to original mass of cell filter media (plus filtrate):

$$
S=\mathrm{f}(V, \theta, v, d, \varphi, w, G)
$$

where:

$V=$ speed of cleaning equipment over the pavement;

$\theta=$ angle of the cleaning jets;

$v=$ air velocity in the cleaning jets;

$d, \varphi=$ define the geometry of the cupules;

$w=$ width of drainage conduit; and

$G=$ gradation of the filter media. 


\section{Inferences}

Real life experience with typical street cleaners and conventional PICP has been disappointing, because conventional sweepers generate limited cleaning depths, and only partly restore infiltration rates, even though the clogging of drainage cells in PICPs is mostly in the upper layers of the filter media. New RCPPs, designed for rapid and routine cleaning by conventional regenerative air street sweeping equipment, are described. The performance of the new RCPP is demonstrated using a purpose built laboratory rig, and by slow motion videos of the observed scour-removal.

The demonstration suggests that RCPPs with drainage cells incorporating special cupules that facilitate rapid and thorough removal may be readily restored by regenerative air street cleaning equipment operated at practical speeds and in a single pass. Conduits in the RCPPs provide the required controlled drainage flows, and the blocks meet safety standards for handicapped and other users, as well as certain proprietary criteria for mass production.

Concrete RCPPs have been manufactured and are now undergoing field tests, and the results will soon be reported in follow-up papers.

\section{Acknowledgments}

This paper is not a final report on comprehensive, completed field trials, but a description of experiments that set out to prove the rapid cleanout concepts. Field trials are being carried out during 2016.

Experiments were conducted on a test rig and sample RCPP blocks designed, built and tested by Bill James. Harald von Langsdorff rendered the concept practical, and designed the moulds for the blocks. Sand and grit was kindly supplied by Mark Latyn of Capital Paving Inc. Jeff MacDonald, Amaco Equipment, Mississauga kindly supplied helpful details on regenerative-air sweepers, and permitted the use of two figures.

Patent applications for the new blocks have been filed.

\section{References}

Bean, E. Z., W. F. Hunt and D. A. Bidelspach. 2005. "Surface Infiltration Rate of Permeable Pavements." Journal of Water Management Modeling R223-22. https://doi.org/10.14796/JWMM.R223-22.

Bean, E. Z., W. F. Hunt and D. A. Bidelspach. 2007a. “Evaluation of Four Permeable Pavement Sites in Eastern North Carolina for Runoff Reduction and Water Quality Impacts." Journal of Irrigation and Drainage Engineering 133 (6): 583-92. https://doi.org/10.1061/(ASCE)0733-9437(2007)133:6(583).

Bean, E. Z., W. F. Hunt and D. A. Bidelspach. 2007b. “Field Survey of Permeable Pavement Surface Infiltration Rates." Journal of Irrigation and Drainage Engineering 133 (3): 249-55.
https://doi.org/10.1061/(ASCE)0733-9437(2007)133:3(249), 249-255.

Brattebo, B. O. and D. B. Booth. 2003. “Long-Term Stormwater Quantity and Quality Performance of Permeable Pavement Systems." Water Research 37 (18): 4369-76. https://doi.org/10.1016/S0043-1354(03)00410-X

Chopra, M., S. Kakuturu, C. Ballock, J. Spence and M. Wanielista. 2010. "Effect of Rejuvenation Methods on the Infiltration Rates of Pervious Concrete Pavements." Journal of Hydrologic Engineering 15 (6): 426-33. https://doi.org/10.1061/(ASCE)HE.1943-5584.0000117

Drake, J. and A. Bradford. 2013a. "Assessing the Potential for Rehabilitation of Surface Permeability Using Regenerative Air and Vacuum Sweeping Trucks." Journal of Water Management Modeling R246-16. https://doi.org/10.14796/JWMM.R246-16.

Drake, J. and A. Bradford. 2013b. "Assessing the Potential for Restoration of Surface Permeability for Permeable Pavements Through Maintenance." Water Science and Technology 68-(9): 195-8. https://doi.org/10.2166/wst.2013.450

Gerrits, C. and W. James. 2002. "Restoration of Infiltration Capacity of Permeable Pavers." In Global Solutions for Urban Drainage: Proceedings of the Ninth International Conference on Urban Drainage (9ICUD), edited by Eric W. Strecker and Wayne C. Huber. Reston, VA: American Society of Civil Engineers. https://doi.org/10.1061/40644(2002)77.

Henderson, V. and S. Tighe. 2011. “Evaluation of Pervious Concrete Pavement Permeability Renewal Maintenance Methods at Field Sites in Canada." Canadian Journal of Civil Engineering 38 (12): 1404-13. https://doi.org/10.1139/111-105.

James, R., W. James and H. von Langsdorff. 2001. “Stormwater Management Model for Environmental Design of Permeable Pavement." Journal of Water Management Modeling R207-26. https://doi.org/10.14796/JWMM.R207-26.

James, W. 2000. “Towards Smart, Benign Urban Water Infrastructure." Journal of Water Management Modeling R206-02. https://doi.org/10.14796/JWMM.R206-02.

James, W. 2004. "Clogging of Permeable Concrete Block Pavement by Street Particulates and Rain." Journal of Water Management Modeling R220-29. https://doi.org/10.14796/JWMM.R220-29.

James, W. and C. Gerrits. 2003. “Maintenance of Infiltration in Modular Interlocking Concrete Pavers with External Drainage Cells." Journal of Water Management Modeling R215-22. https://doi.org/10.14796/JWMM.R215-22.

James, W. and M. K. Thompson. 1997. “Contaminants from Four New Pervious and Impervious Pavements in a Parking Lot." Journal of Water Management Modeling R195-11. https://doi.org/10.14796/JWMM.R195-11. 
James, W. and B. Verspagen. 1997. "Thermal Enrichment of Stormwater by Urban Pavement." Journal of Water Management Modeling R195-08. https://doi.org/10.14796/JWMM.R195-08.

Kipkie, C. and W. James. 2000. “Feasibility of a Permeable Pavement Option in SWMM for Long Term Continuous Modeling." Journal of Water Management Modeling R206-18. https://doi.org/10.14796/JWMM.R206-18.

Kresin, C., W. James and D. Elrick. 1997. "Observations of Infiltration through Clogged Porous Concrete Block Pavers." Journal of Water Management Modeling R195-10. https://doi.org/10.14796/JWMM.R195-10.

Lucke, T. and S. Beecham. 2011. “Field Investigation of Clogging in a Permeable Pavement System." Building Research and Information 39 (6): 603-15. https://doi.org/10.1080/09613218.2011.602182.

Nichols, P. W., R. White and T. Lucke. 2015. “Do Sediment Type and Test Durations Affect Results of Laboratory-Based, Accelerated Testing Studies of Permeable Pavement Clogging?" The Science of the Total Environment 511:786-91. https://doi.org/10.1016/j.scitotenv.2014.12.040.

Pratt, C. J., J. D. G. Mantle and P. A. Schofield. 1995. “UK Research into the Performance of Permeable Pavement, Reservoir Structures in Controlling Stormwater Discharge Quantity and Quality." Water Science and Technology 32 (1): 63-9.

Sansalone, J., X. Kuang and V. Ranieri. 2008. "Permeable Pavement as a Hydraulic and Filtration Interface for Urban Drainage." Journal of Irrigation and Drainage Engineering 134 (5): 666-74. https://doi.org/10.1061/(ASCE)0733-9437(2008)134:5(666), 666-674.
Sansalone, J. and Z. Teng. 2004. In Situ Partial Exfiltration of Rainfall Runoff-1: Quality and Quantity Attenuation. Journal of Environmental Engineering 130 (9): 990-1007. https://doi.org/10.1061/(ASCE)0733-9372(2004)130:9(990), 990-1007.

Schueler, T. R. 1987. Controlling Urban Runoff: A Practical Manual for Planning and Designing Urban BMPs. Washington, DC: Metropolitan Washington Council of Governments.

Shahin, R. 1994. Leaching of Pollutants from Four Pavements using Laboratory Apparatus. Guelph: University of Guelph. M.Sc. Thesis.

Thompson, M. K. 1995. Design and Installation of Test Sections of Porous Pavements for Improved Quality of Parking Lot Runoff. Guelph: University of Guelph. M.Sc. Thesis.

Thompson, M. K. and W. James. 1995. "Provision of Parking Lot Pavement for Surface Water Pollution Control Studies." Journal of Water Management Modeling R183-24. https://doi.org/10.14796/JWMM.R183-24.

TRCA. 2015. Five-Year Evaluation of Permeable Pavements-Kortright Centre, Vaughan, Ontario. Toronto: TRCA. http://www.sustainabletechnologies.ca/wp/home/urbanrunoff-green-infrastructure/low-impact-development/ permeable-pavement/evaluation-of-permeable-pavements-in-cold-climates-kortright-centre-vaughan-ontario/.

Winston, R., A. Al-Rubaei, G. Blecken, M. Viklander and W. Hunt. 2016. "Maintenance Measures for Preservation and Recovery of Permeable Pavement Surface Infiltration Rate-The Effects of Street Sweeping, Vacuum Cleaning, High Pressure Washing, and Milling." Journal of Environmental Management 169:132-44. https://doi.org/10.1016/j.jenvman.2015.12.026. 